\title{
Development of a Physics Practicum Model Using Augmented Reality Technology: A Preliminary Analysis
}

\author{
Widiasih $^{1}$, Henny Johan ${ }^{2, *}$ and Paken Pandiangan ${ }^{1}$ \\ ${ }^{1}$ Department of Physics Education, FKIP, Universitas Terbuka, Tangerang Selatan \\ ${ }^{2}$ Magister of Science Education Program, FKIP, Universitas Bengkulu, Bengkulu \\ *Corresponding author. Email: hennyjohan@unib.ac.id
}

\begin{abstract}
One of the uses of technology in the education sector is the use of Augmented Reality technology in learning. This study aims to analyse the use of augmented reality in learning activities especially at practicum activities. The potential use of augmented reality in practicum activities through literature analysis. This study uses a qualitative descriptive method. Based on the results of literature analysis, it is known that augmented reality has several advantages. The advantages of Augmented Reality are as follows: 1) More interactive, 2) Effective in use, 3) Can be widely implemented in various media, 4) Simple object modelling, because it only displays a few objects, 5) Making that doesn't take too much cost, 6) Easy to operate. Based on the results of field observations, it is known that many students have difficulty completing basic physics practicum. The problem is the difficulty in finding partners. Another difficulty is the difficulty in getting facilities. There are no supplements available that can help to gain hands-on practical experience. Based on the results of the analysis, it can be concluded that augmented reality can be used to assist basic physics practicum activities. It needs to develop supplementary assisted by augmented reality to assist the process of practicum activities.
\end{abstract}

Keywords: Model practicum, Augmented reality, Fundamental physics, Preliminary analysis.

\section{INTRODUCTION}

Globalization are now entering the era of industrial revolution 4.0. The technology of information has become the basis of human life [1]. The industrial revolution 4.0 has changed the pattern of life and the way of humans working. The 4.0 industrial revolution provides challenges and also impacts for the young generation. It also impacts the aspect of education in Indonesia. The development of the 4.0 industrial revolution is marked by the digitalization of the education system. It focuses every element in the education sector to be able to make adjustments to the rate of change that was occurring [2].

The utilization of technology in the education sector is the implementing of the augmented reality in learning activity. According to Wang [3], it indicates that augmented reality (AR) is a technology that visually add the real-world environment by projecting it to the interface of computer. They also stated that research on using of augmented reality is growing faster. Research objectives is to explain the integrating between virtual and real condition. Thus AR can mean that real objects in real time are added with virtual objects that appear when using tools or devices on these real objects. This presents a connection between the virtual world and the real world with the help of a camera. The camera records what is in the real world and displays it on a computer or smartphone screen. This visualization process uses the help of special markers. This special marker can add a virtual three-dimensional appearance to a computer or smartphone screen. The using of augmented reality technology can be seen at Figure 1 .

The Physics Practicum course is part of the compulsory courses at the Universitas Terbuka. Based on the results of field observations, it was found that many students had difficulty completing the physics practicum course. This is because of limitations in finding relationships that can facilitate practicum activities. This is also due to the unavailability of supplements which can help to gain hands-on practical experience. The use of technology in learning activities encourages lecturers to be able to develop the supplementary in practicum courses. Supplementary in 
the practicum course is expected to help practicum activities run more optimally. Thus, there needs to be solutions and alternatives in using technology to support the implementation of physics practicum course activities. Practical lectures at UT require a special strategy to facilitate face-to-face activities and face-toface meetings. In the physics practicum course, students are expected to have direct experience in carrying out physics practicum procedures. The obstacle in the field is the difficulty of establishing relationships with other campuses as partners who can facilitate all practicum subjects. This causes the practicum activities not run effectively.

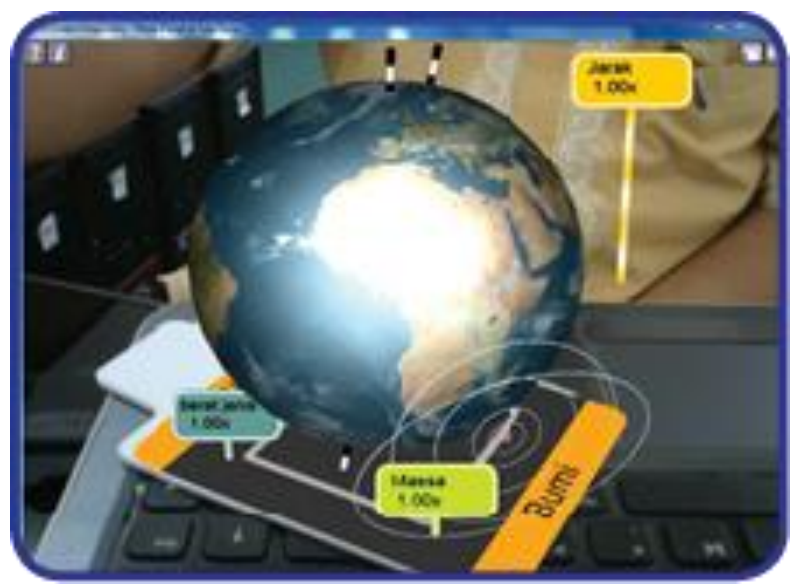

Figure 1. The using of augmented reality in learning earth science

\section{METHOD}

\subsection{Research Design}

This study used descriptive qualitative method. Collecting data used was two types of questionnaire. The questionnaire using to collect data related the rill condition of practicum course especially fundamental physics. The description also focus to the need of the using augmented reality technology in practicum activities.

\subsection{Research Subject}

84 respondents from 7 university in Indonesia. Respondents in this research came from Universitas Bengkulu, Universitas Terbuka, universitas tanjungpura, universitas jember, universitas sriwijaya, universitas pendidikan Indonesia, STKIP Bima, Universitas terbuka UPJJ Batam. Respondents are undergraduate students who are currently taking basic physics courses and who have passed basic physics courses.

\subsection{Instruments for Collecting Data}

Questionnaire and open ended questions were used to collect data about student's responses related to the real condition of practicum activity and the responses of the need of practicum supplementary. 35 questions are create in the questionnaire. The sample of the question in questionnaire can be seen at Table 1 .

Table 1. The sample of the question in questionnaire

\begin{tabular}{|l|l|}
\hline No & \multicolumn{1}{|c|}{ Sample of question } \\
\hline 1 & $\begin{array}{l}\text { Do you feel there are many obstacles in basic } \\
\text { physics practicum 2? }\end{array}$ \\
\hline 2 & $\begin{array}{l}\text { Do you find the practicum procedures written } \\
\text { in the manual easy for you to follow? }\end{array}$ \\
\hline 3 & $\begin{array}{l}\text { Do you feel that the practicum procedures in } \\
\text { the manual are equipped with pictures that } \\
\text { make it easier for you to do each stage of the } \\
\text { practicum steps? }\end{array}$ \\
\hline 4 & $\begin{array}{l}\text { Do you feel that the practicum book needs to be } \\
\text { equipped with images and even augmented } \\
\text { reality related to video procedures in doing } \\
\text { basic physics practicum 2? }\end{array}$ \\
\hline 5 & $\begin{array}{l}\text { In your opinion, can the practicum manual } \\
\text { which is equipped with augmented technology } \\
\text { help students and practicum assistants? }\end{array}$ \\
\hline 6 & $\begin{array}{l}\text { Do you feel that you get optimal guidance in } \\
\text { doing basic physics practicum? }\end{array}$ \\
\hline 7 & $\begin{array}{l}\text { Do you find it easy to follow the procedures for } \\
\text { doing practicum? }\end{array}$ \\
\hline 8 & $\begin{array}{l}\text { Do you feel that you get optimal guidance in } \\
\text { doing basic physics practicum? }\end{array}$ \\
\hline
\end{tabular}

\section{RESULTS AND DISCUSSION}

The data of the rill condition of practicum course especially fundamental physics and the need of the using augmented reality technology in practicum activities were collected by questionnaire. The recapitulation of the result can be seen at Table 2 . Based on Table 2, it's known that $47,6 \%$ of total respondent state that there are many obstacles in basic physics practicum. It indicates that must be a solution to the practicum manual. It also relevant with the statement that $40,5 \%$ of total respondent give testify that they get not optimal guidance in doing basic physics practicum. $78,6 \%$ of total respondent agree that that the practicum procedures in the manual are equipped with pictures that make it easier to do each stage of the practicum steps. This statement shows us that visualization in the manual practicum is important.

This study also collecting the data about the need of any visualization using in the practicum manual especially the using of augmented reality technology. $91,7 \%$ of total respondent agree that the practicum manual which is equipped with augmented technology help students and practicum assistants. Visualization using augmented technology can provide dynamic visualization and the real condition of practicum 
procedure. This result also relevant with the respond from open ended question. Respondent give testify that practicum handbook have many weakness are as follow: technology that can visualize real conditions into a computer interface. AR technology can be used in various fields including learning. Augmented reality is

Table 2. The recapitulation of the result

\begin{tabular}{|c|c|c|c|}
\hline \multirow[t]{2}{*}{ No } & \multirow[t]{2}{*}{ questions } & \multicolumn{2}{|c|}{ respond } \\
\hline & & Yes (\%) & No (\%) \\
\hline 1 & $\begin{array}{l}\text { Do you feel there are many obstacles in basic physics practicum } \\
2 \text { ? }\end{array}$ & 47,6 & 52,4 \\
\hline 2 & $\begin{array}{l}\text { Do you find the practicum procedures written in the manual easy } \\
\text { for you to follow? }\end{array}$ & 89,3 & 10,7 \\
\hline 3 & $\begin{array}{l}\text { Do you feel that the practicum procedures in the manual are } \\
\text { equipped with pictures that make it easier for you to do each stage } \\
\text { of the practicum steps? }\end{array}$ & 89,3 & 10,7 \\
\hline 4 & $\begin{array}{l}\text { Do you feel that the practicum book needs to be equipped with } \\
\text { images and even augmented reality related to video procedures in } \\
\text { doing basic physics practicum } 2 \text { ? }\end{array}$ & 78,6 & 21,4 \\
\hline 5 & $\begin{array}{l}\text { In your opinion, can the practicum manual which is equipped with } \\
\text { augmented technology help students and practicum assistants? }\end{array}$ & 91,7 & 8,2 \\
\hline 6 & $\begin{array}{l}\text { Do you feel that you get optimal guidance in doing basic physics } \\
\text { practicum? }\end{array}$ & 59,5 & 40,5 \\
\hline 7 & Do you find it easy to follow the procedures for doing practicum? & 81 & 19 \\
\hline 8 & $\begin{array}{l}\text { Do you feel that you get optimal guidance in doing basic physics } \\
\text { practicum? }\end{array}$ & 59,5 & 40,5 \\
\hline
\end{tabular}

1. Not all experiments are accompanied by pictures; there is a picture but there is no explanation

2. There are some guides that do not match the real situation

3. No animated videos or real experimental images are included

4. Unclear activity steps

5. Less simple sentences

6. Sometimes work procedures are confusing because we are just groping

7. Physics practicum will be difficult to understand

8. There is no picture of the practicum series

9. the book is not updated

10. the practicum guide may not be complete

11. In the manual sometimes does not explain the objectives in the steps to be implemented

12. Lack of guides does not include animated videos or real experimental images.

13. Sometimes work procedures are confusing because we are just groping

14. Physics practicum will be difficult to understand

There have been many studies that focus on the application of augmented reality technology in learning activities. Synergy with the results of previous studies which state that Augmented Reality (AR) is a able to present dynamic images that make it easier to

understand concepts in learning activities. Augmented realty is also able to present real objects to support learning [4], [5], [6]. Media visual can help to understand concept easy, include bring the model of authentic data during learning physics [7][8][9]. Visualization from authentic data can bring rill condition of nature along the learning or practicum activity [10].

Respondent give testify that practicum activity have many obstacles. They testify that the obstacles are as follow:

1. Practical procedure does not make a suitable practicum

2. Must find laboratory that were open during a pandemic

3. Time often clashes with teaching hours

4. Constraints in understanding modules that only contain writing without complete picture guides

5. The problem is sometimes in tools such as viscous tabs which are not long enough, then there are also problems in the materials used, sometimes they are used many times so that the level of accuracy is reduced 
6. Instructors who sometimes let the practitioner do the practicum by themselves without being guided

7. There are not so many obstacles in the implementation of physics practicum, it's just that writing reports that are burdensome for the practitioner should be simplified more so that it is efficient

8. The constraints felt the most during online lectures, namely incompleteness and facilities that understand make practicum activities ineffective

9. The only problem is that I cannot video call the instructor because there is no internet network at my practicum.

\section{CONCLUSION}

In summary, augmented reality can be used to assist basic physics practicum activities. It needs to develop supplementary material assisted by augmented reality to assist the process of practicum activities. Augmented technology assists student during the practicum procedures.

\section{ACKNOWLEDGMENTS}

The authors acknowledge Septi Johan, M.Si and all parties that gave contribution in this study.

\section{REFERENCES}

[1] Matsun, M., Ramadhani, D., \& Lestari, I. Jurnal Pendidikan Informatika Dan Sains. (2018).
[2] Zidniyati. Tarbiyah, 3(1), 1-17. https://doi.org/10.1145/3132847.3132886. (2018).

[3] Wang, Y. J., Chen, P. J., Liang, X., \& Lin, Y. H. Scientific Reports. https://doi.org/10.1038/s41598017-00492-2. (2017).

[4] Chen, Y., Wang, Q., Chen, H., Song, X., Tang, H., \& Tian, M. (2019, June). An overview of augmented reality technology. In Journal of Physics: Conference Series (Vol. 1237, No. 2, p. 022082). IOP Publishing.

[5] Kangdon Lee. TechTrends. Volume 56, Number 2 (2012).

[6] Mehmet Kesim, Yasin Ozarslan. Procedia Social and Behavioral Sciences 47(810):297-302 (2012).

[7] Johan H, A Suhandi, A R Wulan, and Sipriyadi, Journal of Turkish Science Education 15(1) 109127. 2018.

[8] Johan H, A Suhandi, A R Wulan, Sipriyadi, A Herawati Jurnal Pendidikan IPA Indonesia 7(4) 435-441, 2018

[9] Johan, H., Suhandi, A., Wulan, A. R., Ruyani, A., \& Karyadi, B. (2018, May). Embedding spiritual value through science learning. In Journal of Physics: Conference Series (Vol. 1013, No. 1, p. 012083). IOP Publishing.

[10] Johan H, A Suhandi, A R Wulan, Sipriyadi. Jurnal Pendidikan Fisika Indonesia 14(1) 7-17. 2018. 